\title{
Exploring UAE Teachers' Attitude towards the Successful Implementation of the General Rules in the "School for All" Initiative
}

\author{
Haytham M. Badr \\ Faculty of Education, The British University in Dubai (BUiD), Dubai, UAE
}

\begin{abstract}
The UAE federal law no. 29 of 2006 was a major step towards the recognition of the right of people with disabilities to receive the same educational, healthcare and recreational services among other services as received by their non-disabled ones. This new trend was later emphasized by the UAE Ministry of Education through some initiatives including the "School for All" initiative which was launched in 2010. This initiative set the general rules for the successful implementation of inclusion in the UAE context. The present study aimed at investigating the implementation of these rules from teachers' perspectives as a precursor of the successful inclusion in the UAE context. To do so, a questionnaire in the form of open-ended and close-ended questions was given out to all teachers of the investigated research site, totaling 194 teachers. However, only 77 teachers responded to the questionnaire, and then formed the main sample of the current study. The results revealed teachers' different attitudes towards the implementation of the general rules in the "School for All" initiative. Some recommendations towards the best teaching strategies that can be adopted to enhance effective teaching and learning in inclusive classes were also provided.
\end{abstract}

Index Terms — teachers' attitude, "School for all” initiative, people with disabilities, inclusive education

\section{INTRODUCTION}

Literature in the history of inclusion in the UAE showed two main reasons why inclusive education was ignored until 1971 and ineffective until 2006. Firstly, Gaad (2004) referred to the lack of educational services provided for disabled students coupled with the absence of laws that defended the right of students with disabilities to receive good quality education until the first draft of the UAE constitution, which stated the right of education for all students regardless of their abilities or disabilities, was issued in 1971 then amended in 1996 (Alahbabi, 2009). Secondly, the inclusive classes in the UAE were dually supervised and managed by the UAE Ministry of Education and the UAE Ministry of Social Affairs, for a long period of time until the new federal law no. 29 of 2006 was issued (Gaad \& Almotairi, 2013). According to them, this dual supervision and management contributed to raising questions about the efficiency of inclusive education in the UAE.

The issuance of the UAE federal law no. 29 of 2006 , as amended later by the law no. 14 of 2009 was considered a shift towards inclusive education in the UAE as it emphasized the right of disabled students to obtain the same high quality education among other services as obtained by their non-disabled peers (Gaad, 2011). Accordingly, the UAE ministry of education (MOE) launched in May 2010 the general rules that govern the integration of disabled students into mainstream classrooms under the "School for All" initiative (MOE, 2010). Since then, these general rules, which revolve mainly around the removal of obstacles that prevent full participation and involvement of disabled students with the aim of providing equal educational opportunities for all students (MOE 2010), have been constituting the main reference for any successful implementation of inclusion in the UAE (Gaad \& Almotairi, 2013). These general rules were divided by the researcher into the following five categories and then investigated throughout this study based on their implementation in the UAE inclusive classes from teachers' perspective: (1) teachers' capabilities in terms of training, experience and qualifications, (2) teachers' responsibilities, (3) rights of parents of disabled students, (4) organizational structure of schools, (5) curricular and assessment systems.

\section{Purpose, SCOPE AND RESEARCh Question}

A considerable number of studies were conducted to explore teachers' attitude and perception towards integrating students with disabilities into general education classes in the UAE to check the possibility of successful inclusion in the UAE (Alahbabi, 2009; Anati, 2012; Gaad \& Khan, 2007). According to the results of these studies, UAE teachers believed in the right of students with disabilities to receive equal educational services as provided for their non-disabled ones with some worries regarding the impact of inclusion on both disabled and non-disabled students' academic and social development as a result of the lack of teachers' necessary training and experience that enable them to deal with different academic and disciplinary issues (Alahbabi, 2009), the lack of methods and strategies that enhance the successful implementation of integration of disabled students into mainstream classrooms (Anati, 2012) and the lack of 
appropriate contents and other necessary resources that bridge the gap between typically achieving and disabled students (Gaad \& Khan, 2007).

However, and to the best of the researcher knowledge, no attempts were made to explore the perception of stakeholders of the educational process towards the successful application of the general rules of several inclusive education initiatives launched by the UAE Ministry of Education in coordination with the UAE government. Here came the significance of this study as being the first of its kind in the UAE to make a contribution to the literature in this crucial area of research. To make the current research more specific and more focused, the researcher has decided to explore teachers' perception towards the successful application of the general rules of a pioneering initiative launched in May 2010 by the UAE Ministry of Education and called the "School for All" initiative.

The researcher, on his way to find an answer to the research question below, hypothesizes that UAE teachers have a positive attitude against the five main categories in the "School for All" initiative as a result of the ever-continuing effort and encouragement by the UAE Ministry of Education towards the application of inclusive education at all governmental and private schools:

What are UAE teachers' attitudes towards the successful implementation of the five categories in the "School for All" initiative?

\section{LITERATURE REVIEW}

\section{A. Theoretical Framework}

The term "attitude" is well-defined by Ajzen (2011) as the tendency of individuals to evaluate a thing in terms of having a positive or negative impact. This term is also defined by Albarracin, Zanna, Johnson and Kumkale (2005) as the individual's response to a matter and this response is governed by his/her inner desire. To explain this in other words, the attitude of an individual towards a thing affects, to a certain degree, on his/her behavior or response towards it. Based on that, literature shows some attempts by theorists and researchers to understand the nature of the relationship between attitude and human behavior, leading to the emergence of some leading theories including the attitude-behavior theories which are considered by Sutton (1998) the most popular theories to explain the relationship between attitude and human behavior. According to him, these theories are the most popular because they are simple to understand, easy to operate and accurate in predicting human behavior, however; the three main theories of which are identified by Zint (2002) as: (1) the theory of reasoned action, (2) the theory of planned behavior, (3) the theory of trying. The following lines provide a critical review of these three main theories.

According to Ajzen and Fishbein (2002), the theory of reasoned action posits that individuals' response to a thing is totally directed by their desire or tendency to perform that thing. For example, if educators have the desire or tendency towards inclusive education, this means that they are bound to have a more positive attitude towards inclusive education and vice versa. Nevertheless, this theory is put into question by Cooper, Crano and Forgas (2010) and Ajzen (2011) for being limited to predicting only the behavior that can volitionally and voluntarily be controlled by individuals. The theory of reasoned action is followed by the theory of planned behavior in which individuals' attitude or response towards an act is partially, but not totally, dependent on individuals' desire or tendency to perform that act (Ajzen, 2011). He goes on to say that individuals' response to an act is closely connected with their beliefs towards that act. For example, if educators believe in the effectiveness of inclusive education in enhancing learning outcome, it is an indicator that they tend to have a more positive attitude towards inclusive education and vice versa.

Lastly, and as argued by Zint (2002) and Carsrud, Brannback, Elfving and Brandt (2009), the theory of trying is an expansion of the theory of planned behavior, in which individuals' response to a behavior depends heavily on individuals' evaluation of the outcome in terms of advantages and disadvantages (benefits and risks) of the outcome. For example, if educators think that the inclusion policy is useful to achieve the intended objectives and desired outcomes, this means that they tend to have a more positive attitude towards the inclusion policy and vice versa.

\section{B. Different Models of Disability}

According to French and Swain (2004), it was until early 1970s that disability was defined as a deficiency in the human body that renders it unable to do an activity and also requires providing special health care in segregated places. This definition was later faced by massive criticism by a number of civil society organizations and other grassroots organizations run by disabled individuals for being incorrect or inaccurate, asking for other meanings centered on social exclusion rather than physical deficiency (Finkelstein, 2004). According to Albert (2006), the new definition of disability, based on social exclusion, started to gain worldwide recognition, making a shift in the way people see disabled individuals from being bodily impaired to being socially and environmentally hindered to get access to equal opportunities.

Notwithstanding, many scholars and researchers (e.g., Shakespeare \& Watson, 2009; Albert, 2006; Oliver, 2004) put this social model of disability into question for focusing only on social exclusions and neglecting any bodily impairments, seeking for a new model that takes into account both issues of disability (social exclusions and bodily impairments). The result was the development of other models based on the criticism to the above two models, such as; the social relational model and the affirmation model. The social relational model proposed that the inability of individuals to do an activity does not necessarily mean that they are disabled individuals unless such inability is socially 
recognized as a restriction (Thomas, 2004). On the other hand, the affirmation model rejected the medical view of disability and affirmed the positive identity of disabled people (French \& Swain, 2004). They continued to say that disabled individuals can live a normal life full of positive and negative experiences, and they are required to show or affirm their positive identity through other activities.

However, and despite the criticism to the social model of disability, it is still effective in the UN convention on the rights of persons with disabilities (UN, 2006). According to this convention, disabled individuals are untapped potential, and these untapped potential should be developed through high-quality education and full involvement in all facets of life for the benefit of the whole society. It also emphasizes the importance of overcoming the barriers that may impede their contribution to the society, such as; transport and communication systems, inaccessible buildings, inflexible practices and procedures, improper training and uneven educational opportunities among other barriers.

\section{Disability and Inclusion-related Issues in the UAE}

Disabled people in the UAE are still looked at from the medical perspective of disability which emphasizes their need to therapeutic intervention, segregated settings and special rehabilitation (Arif \& Gaad, 2008). This cultural belief among people in the UAE explains why some improper words such as "disadvantaged" and "suffering" are still used in the media language and in the official statements and formal announcements across the country (Bladd, 2010), or even written and kept in students' achievement records such as "Mongols" and "retarded" as demonstrated in the study conducted by Arif and Gaad (2008). Adding to this, Gaad (2011) contends that, although it is regulated in the UAE constitution that disabled individuals have the same rights as received by non-disabled ones, these rights are still given to them in the form of a charity by the society.

It is then concluded that the previous laws and initiatives calling for equal opportunities for people regardless of their abilities or disabilities are insufficient to introduce or explain the accurate meaning of disability, leading to obvious confusion on how disabled individuals' rights are practiced or supported. Therefore, the UAE government and its establishments still have lots of work to do to raise the awareness of people regarding the accurate meaning of disability. For example, the UAE Ministry of Education needs to launch more initiatives or hold further conferences to raise the awareness among stakeholders of the educational process, including teachers, principals, administrators and parents of disabled students, of the social and academic rights of students with disabilities, as being the first step on the right way to achieve effective and successful inclusion in the UAE context (Anati, 2012).

\section{Methodology}

\section{A. Research Design}

As mentioned earlier in the first section of this research, the researcher has decided to explore the application of the five categories in the "School for All" initiative; teachers' capabilities, teachers' responsibilities, rights of parents of disabled students, organizational structure of schools and curricular and assessment systems, from teachers' perspective. For the purpose of conducting the implementation stage and collecting the current research data, the questionnaire, which is a type of surveys that provides accurate numerical data on an educational phenomenon as contended by Gall, Gall and Borg (2007), was fully developed then used by the researcher of the current study.

The current research tool, the questionnaire, was divided by the researcher into three parts as shown in the appendix (A) to this research; the first part of which was developed to get some demographic information about the participants, and the second part was designed to answer the present research question, while the third part was mainly designed to obtain some detailed information that cannot be obtained from the quantitative data in the second part of the questionnaire. Therefore, it was believed by the researcher that the current tool is the best to gather the necessary information required to accurately and elaborately answer the current research question.

\section{B. Participants and Research Sites}

After getting the necessary approvals from the official representatives of the investigated research site, a well-reputed private K-12 school in Dubai, the questionnaire was sent to the administration department which took its part in delivering the questionnaire to all teachers of the investigated school, a total of 194 teachers. According to the demographic information from the questionnaire, only 77 out of 194 teachers (44 males and 33 females) from different educational levels responded to the questionnaire and then formed the main sample of the study. Two different curricular; one follows the MOE curriculum and the other follows a US curriculum, have been applied in our research site, allowing for various academic subjects to be taught by different specialized teachers. The current research site was particularly chosen because it accepts students of different disability categories to study in its classes. More detailed information about the participants was provided in the "data analysis and results" section below.

\section{Materials and Procedures}

The general rules of the "School for All" initiative as introduced by the UAE Ministry of Education and attached as a separate file to this research, were used to be the current research material to explore teachers' attitude towards their successful application in the UAE context. The main data of the research was collected using a five-point Likert scale, ranging from strongly agree $=5$ points, agree $=4$ points, neutral $=3$ points, disagree $=2$ points, to strongly disagree $=1$ 
point. The reliability test was administered to each category after the data was collected to ensure the reliability of the collected data on Cronbach's alpha as a pre-requisite to make accurate analysis and obtain reliable results. The total attitude was then utilized to measure teachers' attitude towards the successful implementation of the general rules in the initiative; namely, each score mean above 3 points indicates a positive attitude and each score mean below 3 points implies a negative attitude.

\section{Ethical, Entry, Validity and Reliability Issues}

The researcher of this study was fully aware of the importance of the following: (1) getting the necessary approvals from the research site's principal and other official representatives, (2) arranging a date with the administration department to send the questionnaire and receive the participants' responses, (3) reassuring the avoidance of disseminating any information that would cause any harm to the research site and/ or the academic staff, (4) keeping the name of the research site anonymous as requested by the school principal, (5) explaining the purpose of the research whenever asked to do so. Therefore, all these issues were taken into account by the researcher and assured in a meeting with the principal of the investigated school before starting the implementation stage of the research.

Moreover, Creswell (2014) suggested many techniques and strategies to enhance the accuracy of the results of the questionnaire, and one of which was to assign an external judge to check all questions in the questionnaire. Therefore, all comments as made and provided by the external judge were inserted in the final version of the questionnaire. Similarly, many strategies and techniques were suggested by Creswell (2014) to ensure the reliability of the research results, and one of which was to confirm the repetition of answers to the same or similar questions in the questionnaire. To do so, some questions were repeated using the negative form of the question or synonyms for the central words in the questions, and those repeated questions were then measured using the correlation coefficient test. The result of the test on each repeated question was high, showing high reliability $(\mathrm{p}<0.01, r s=1)$.

\section{DATA ANALYSIS AND RESUltS}

The research data is entered, scored, screened and analyzed using the Statistical Program for Social Sciences (SPSS) software package, version 23. The data from the first and second parts of the questionnaire is analyzed using the descriptive statistical analysis and data frequencies analysis to get more information about the participants and answer the research question respectively. Before conducting the data frequencies analysis, the data reliability test is administered to each category in the general rules of the investigated initiative to ensure the reliability of the collected data on Cronbach's alpha scale leading to more accurate analysis and more reliable results.

\section{A. Demographic Information of the Participants}

TABLE I.

PARTICIPANTS' DEMOGRAPHIC INFORMATION

\begin{tabular}{|c|c|c|}
\hline Characteristics & Participants & \\
\hline \multirow{2}{*}{ Sex } & Male & 44 \\
\hline & Female & 33 \\
\hline \multirow{5}{*}{ Age } & 55 - Above & 4 \\
\hline & $46-54$ & 20 \\
\hline & $36-45$ & 26 \\
\hline & $26-35$ & 24 \\
\hline & 25-Below & 3 \\
\hline \multirow{4}{*}{ Qualifications } & P.h.D & 2 \\
\hline & Master & 14 \\
\hline & Post-Graduate & 23 \\
\hline & Bachelor & 38 \\
\hline \multirow{4}{*}{$\begin{array}{l}\text { Total } \\
\text { Teaching } \\
\text { Experience }\end{array}$} & 10-More & 35 \\
\hline & $6-9$ & 28 \\
\hline & $3-5$ & 14 \\
\hline & 2-Less & 0 \\
\hline \multirow{3}{*}{$\begin{array}{l}\text { Total } \\
\text { Teaching } \\
\text { Experience in } \\
\text { Inclusive } \\
\text { Classes }\end{array}$} & 5-More & 7 \\
\hline & $2-4$ & 67 \\
\hline & 1-Less & 3 \\
\hline \multirow{4}{*}{$\begin{array}{l}\text { Educational } \\
\text { School Level }\end{array}$} & $\mathrm{KG}$ & 14 \\
\hline & Primary & 20 \\
\hline & Preparatory & 22 \\
\hline & Secondary & 21 \\
\hline \multirow{4}{*}{$\begin{array}{l}\text { Number of } \\
\text { Inclusive } \\
\text { Courses } \\
\text { Attended }\end{array}$} & 5 - More & 5 \\
\hline & $3-4$ & 12 \\
\hline & $1-2$ & 60 \\
\hline & No courses & 0 \\
\hline
\end{tabular}


The table (1) above describes all demographic information about the participants including their gender, age, educational level, total teaching experience, total teaching experience in inclusive classes, educational school level and finally number of courses or programs attended by the participants. It is quite apparent from the table above that all participants know about inclusive education by attending at least one to two courses or programs (77.9\%) and have teaching experience in inclusive classes no less than two years $(87 \%)$. The table also shows that the percentage of participation among male $(57.1 \%)$ is higher than the percentage of participation among female (42.9\%), and those who have an academic degree beyond the bachelor degree constitute almost half the sample with only two and half percent to those who have the $\mathrm{PhD}$ degree. Finally, the table shows no big fluctuation in the distribution of teachers among different educational school levels in comparison to the great fluctuation among age groups and qualification levels.

\section{B. Teachers' Attitude}

Before conducting the data frequencies analysis to measure the frequencies of teachers' responses, each of the following five categories is tested separately to check the reliability of data on Cronbach's alpha: teachers' capabilities, teachers' responsibilities, parents' rights, organizational structure and curricular and assessment systems. The actual value for each category on Cronbach's alpha is registered as follows: $(0.864),(0.740),(0.847),(0.860)$ and $(0.887)$ respectively. Since these values are greater than (0.7) on Cronbach's alpha, this means that the data is reliable, and then, the data frequencies test can be employed.

Furthermore, and to make the data collected from the Likert scale more organized, all responses towards each question are calculated then ranked from the highest to the lowest value based on the score mean of each question as presented in table (2) below. The total attitude is used; namely, the score means above three points indicate positive attitudes while the score means below three points imply negative attitudes towards the successful implementation of the general rules in the "School for All" initiative.

TABLE II.

TEACHERS' RESPONSES

\begin{tabular}{|c|c|c|c|}
\hline $\begin{array}{l}\text { No. of the } \\
\text { question as per } \\
\text { the questionnaire }\end{array}$ & $\begin{array}{l}\text { No. of the question after } \\
\text { being ranked based on } \\
\text { the score mean }\end{array}$ & M & SD \\
\hline Ques. 8 & 20 & 2.14 & 9.56 \\
\hline Ques.9 & 18 & 2.66 & 1.263 \\
\hline Ques. 10 & 17 & 2.84 & 1.040 \\
\hline Ques. 11 & 19 & 2.15 & 0.986 \\
\hline Ques. 12 & 1 & 4.30 & 0.844 \\
\hline Ques. 13 & 3 & 4.00 & 0.585 \\
\hline Ques. 14 & 15 & 3.02 & 0.727 \\
\hline Ques. 15 & 5 & 3.94 & 0.800 \\
\hline Ques. 16 & 2 & 4.06 & 0.833 \\
\hline Ques. 17 & 8 & 3.79 & 0.817 \\
\hline Ques. 18 & 10 & 3.58 & 0.894 \\
\hline Ques. 19 & 11 & 3.44 & 1.032 \\
\hline Ques. 20 & 6 & 3.83 & 1.031 \\
\hline Ques. 21 & 4 & 3.98 & 0.844 \\
\hline Ques. 22 & 13 & 3.17 & 0.992 \\
\hline Ques. 23 & 16 & 3.01 & 0.917 \\
\hline Ques. 24 & 7 & 3.81 & 0.744 \\
\hline Ques. 25 & 9 & 3.65 & 0.870 \\
\hline Ques. 26 & 12 & 3.34 & 1.008 \\
\hline Ques. 27 & 14 & 3.13 & 0.937 \\
\hline
\end{tabular}

The table above describes teachers' attitude towards the five main categories in the "School for All" initiative; teachers' capabilities, teachers' responsibilities, rights of parents of students with disabilities, organizational structure of schools and curricular and assessment systems. It can be noticed from the table above that teachers tend to have a negative attitude towards teachers' capabilities in comparison to the positive attitude towards the other four categories. More specifically, no positive attitudes are indicated from all questions in the first category (score means $=2.14,2.66$, $2.84 \& 2.15$ respectively), unveiling the strong tendency against teachers' capabilities in terms of training, experience and qualifications.

On contrary to the first category, the results obtained from the questions 12 through 27 reveal a positive attitude towards the other four categories, but in varying degrees. In addition, the highest score mean is noticed in the question no. $12(\mathrm{~m}=4.30)$ uncovering teachers' fully understanding of their responsibilities towards their job as inclusive education teachers, while the lowest score mean is seen in the question no. $8(\mathrm{~m}=2.14)$ unveiling the strong belief among teachers that they are not qualified enough to teach in inclusive classes.

Moreover, the data gathered from the question no. 28 reveals that most teachers $(74.6 \%)$ believe in the successful policy of inclusion in the UAE as a result of the ever-continuing effort by the UAE Ministry of Education towards the transition to the inclusive education providing the same high quality education for disabled students as provided for 
their non-disabled peers. However, the majority of teachers $(88.7 \%)$ express their worries of the negative impact of their poor qualifications on students' social and academic development.

In addition, teachers' responses towards the question no. 29 revolve mainly around two issues; the time constraint $(36.8 \%)$ and the lack of suitable materials (43.6\%), claiming that these two issues are easier handled in some classes than others based on the percentage of disparity in students' achievements and disabilities, and there are no such materials that can cover the huge disparity in students' achievements and disabilities in inclusive classes. The only solution as provided by the vast majority of teachers $(95 \%)$ is to adopt the cooperative learning strategies as effective teaching methods to enhance students' high participation and full involvement in classroom activities, as the perfect way, according to them, to handle or overcome the two issues above.

\section{DISCUSSION}

The results of the present study show that teachers have previous knowledge about inclusive education by attending at least one to two courses or programs $(77.9 \%)$ and have teaching experience in inclusive classes no less than two years (87\%). However, this knowledge is not sufficient to qualify teachers, from their standpoint, to teach or deal with disciplinary issues encountered by them in inclusive classes $(\mathrm{m}=2.14)$. This result is very disappointing in the way that teachers' capabilities in terms of training, experience and qualifications are considered crucial by the UAE Ministry of Education as confirmed in the "School for All" initiative to achieve successful inclusion in the UAE context (MOE, 2010). The importance of teachers' training, experience and qualifications in achieving effective inclusion is also asserted by other studies (Engelbrecht, Oswald \& Forlin, 2006; Thorpe \& Azam, 2010; Forlin \& Chambers, 2011).

Adding to this, other studies conducted in the UAE (Gaad \& Khan, 2007; Gaad, 2011; Anati, 2012) agree with the results of this study in which UAE teachers need more specialized training or programs to be able to deal with different disability categories, such as; special learning disabilities (inability to speak, listen, write, read, think or perform mathematical calculations among other learning disabilities), visual and hearing impairment (partially sighted, partially deaf, blindness, deafness), autism and other emotional and behavioral disorders, as explained in details in the "School for All" initiative.

However, the results show that teachers tend to have a positive attitude towards the other four categories of the initiative; teachers' responsibilities, rights of parents of disabled students, organizational structure of schools and curricular and assessment systems. In this regard, Meijer (2003) corroborates that the negative attitude of teachers towards accepting disabled students as an integral part of their responsibilities and jobs, recognizing the rights of parents of disabled students in expressing their concerns and receiving regular feedback about the social and academic development of their children and/ or believing in the rights of disabled students to have adequate services, suitable facilities, modified curricular and proper evaluation systems that best suit them, enhances the tendency towards assigning special education teachers rather than mainstream teachers to teach students with disabilities.

Moreover, teachers' constraints are identified as the lack of ample teaching time and suitable instructional materials for those who are eligible to be admitted to mainstream schools as per the educational provisions of the "School for All" initiative. The results of this study agree with the one carried out by Gaad (2011) in which the time allocated for instruction and the materials used in teaching need to be adjusted if we search for effective teaching and learning in inclusive classes. According to her, the huge disparity in students' abilities should be accompanied with (1) an increase in the instructional time to promote low achievers' learning, (2) adjustments in the instructional materials to suit students' different disability categories.

The result of the insufficient time and unsuitable instructional materials, as argued by Gaad (2011), is ineffective learning in inclusive classes. Kauffman, Landrum, Mock, Sayeski and Sayesk (2005) add the social dimension to the impact of the insufficient time and unsuitable instructional materials on students with disabilities by saying that, the lack of due attention to these two issues increases the chances of segregating students with disabilities inside inclusive classes, especially if teachers deal with students with multi disabilities.

Ultimately, the idea of adopting cooperative learning strategies to promote teaching and learning in inclusive classes as suggested by the investigated teachers is supported by Pavri and Monda-Amaya (2001) who argue that these strategies improve students' social and academic skills through the scaffolding technique during students' interaction. These strategies are also considered a solution by Daniel and King (1997) to remove teachers' concerns regarding the insufficient time and unsuitable material by assigning students to work in pairs or groups. They contend that, if the cooperative learning strategies are used in inclusive classes, the time used by teachers to deal with non-academic issues will be reduced to minimum, and the assistance received by low achieving students from their high achieving peers will reach its maximum.

\section{CONCLUSION, LIMITATION, AND FUTURE RESEARCH}

According to Wolcott (2008), two issues always come to surface with questionnaires; the attitude and behavior issues. He explains this by saying that through questionnaires, (1) it is difficult to understand some certain forms of information such as the change of feelings and emotions, (2) it is difficult to know how much thought the participants have put in, (3) it is impossible to know how truthful the participants are being, (4) people read differently and this may lead to different 
understanding of the questions and then different responses. According to Fetterman (2010), the above two issues can be covered if the interview is used as an auxiliary research tool. However, and because of the limited time allocated to conduct the study, the researcher is unable to use the two tools together to cover the above limitations.

It is concluded from the present study that the current cultural view of people in the UAE towards the meaning of disability needs to be changed. Educationally, further special education training or programs are suggested to be conducted under the supervision of the UAE Ministry of Education and other educational institutions to raise the awareness of stakeholders of the educational process of the correct meaning of disability in addition to the social and academic rights of disabled students. It is also concluded from the results of this study that teachers need more specialized training or courses to reach the level of confidence and certainty that qualify them to teach or deal with different students in inclusive classes.

Unlike the above results, teachers tend to have a positive attitude towards the other four categories in the "School for All" initiative but in varying degrees. Some constraints are identified as the lack of adequate time and suitable instructional materials which, in turn, may result in poor academic development and poor social skills by disabled students. Finally, the current study recommends using cooperative learning strategies as effective teaching methods to achieve effective teaching and learning and to overcome the above constraints.

Notwithstanding, and although the research question is evidently answered, the present study should be interpreted with some caution for the following reasons:

1- The limited number of participants in the questionnaire is a weakness as it raises the issue of the wellrepresentation of the sample for the whole society. Indeed, employing a large number of participants increases the chance of obtaining more invaluable information which may lead to more significant results as a consequence.

2- The limited time allocated for the study refrains the researcher from using the interview as an auxiliary research tool to overcome the questionnaire research tool's limitations explained earlier in the methodology section of the current study.

Therefore, it is recommended by the researcher of the current study to duplicate this study taking into account the limitations above to reach a clear-cut conclusion as well as a generalization regarding the possibility of successful implementation of inclusion in the UAE context. The researcher also recommends more research to be conducted to explore other stakeholders' views, such as; school administrators, school principals and/ or parents of children with disabilities, towards inclusion or towards the successful implementation of inclusion in the UAE. By conducting these studies, the researcher is certain that more significant information can be obtained leading to more constructive recommendations regarding this critical area of research.

\section{APPENDIX. THE QUESTIONNAIRE}

\section{FIRST PART}

Please circle only one answer that is the most suitable for you from each question below.

1. What is your gender?
(a) Male
(b) Female

2. What is your age range?
(a) 55 -above
(b) $46-54$
(c) $36-45$
(d) $26-35$
(e) 25- below

3. What is your educational qualification level?
(a) $\mathrm{PhD}$ degree
(b) Master degree
(c) Post-graduate diploma
(d) Bachelor degree

4. How much is your total teaching experience in the UAE?
(a) 10 years or more
(b) 6-9 years
(c) 3-5 years
(d) 2 or less

5 . What much is your total teaching experience in inclusive classes?
(a) 5 or more
(b) 2-4
(c) 1 or less

6. What is the educational school level you teach?
(a) Kindergarten
(b) Primary
(c) Preparatory
(d) Secondary

7. How many special education programs or courses have you attended?
(a) 5 or more
(b) 3-4
(c) 1-2
(d) Non

\section{SECOND PART}

Please use the following keys to determine the most suitable answers for the questions 8 through 27 .

$(\mathrm{SA}=$ Strongly Agree $=5$ points $/ \mathrm{A}=$ Agree $=4$ points $/ \mathrm{N}=$ Neutral $=3$ points $/ \mathrm{D}=\mathrm{Disagree}=2$ points $/ \mathrm{SD}=$ Strongly Disagree $=1$ point) 
QUESTION 8-11

TEACHERS' CAPABILITIES

\begin{tabular}{|c|c|c|c|c|c|c|}
\hline $\mathbf{S} / \mathbf{N}$ & Items & $\mathbf{S A}$ & $\mathbf{A}$ & $\mathbf{N}$ & D & SD \\
\hline (8) & $\begin{array}{l}\text { I believe that I am } \\
\text { qualified enough to teach } \\
\text { inclusive classes. }\end{array}$ & 5 & 4 & 3 & 2 & 1 \\
\hline (9) & $\begin{array}{l}\text { I think more training or } \\
\text { courses should not be } \\
\text { provided to sharpen my } \\
\text { skills both academically } \\
\text { and socially. }\end{array}$ & 5 & 4 & 3 & 2 & 1 \\
\hline (10) & $\begin{array}{l}\text { The school assigns me to } \\
\text { teach inclusive classes } \\
\text { based on my knowledge } \\
\text { and experience. }\end{array}$ & 5 & 4 & 3 & 2 & 1 \\
\hline (11) & $\begin{array}{l}\text { My experience enables me } \\
\text { to handle all academic, } \\
\text { behavioral and disciplinary } \\
\text { issues in inclusive classes. }\end{array}$ & 5 & 4 & 3 & 2 & 1 \\
\hline
\end{tabular}

QUESTIONS 12-15

TEACHERS' RESPONSIBILITIES

\begin{tabular}{|c|c|c|c|c|c|c|}
\hline $\mathrm{S} / \mathrm{N}$ & Items & SA & A & $\mathrm{N}$ & D & SD \\
\hline (12) & $\begin{array}{l}\text { I totally understand my } \\
\text { duties and responsibilities } \\
\text { as a teacher teaching } \\
\text { inclusive classes' students. }\end{array}$ & 5 & 4 & 3 & 2 & 1 \\
\hline (13) & $\begin{array}{l}\text { I strictly adhere to these } \\
\text { duties and responsibilities. }\end{array}$ & 5 & 4 & 3 & 2 & 1 \\
\hline (14) & $\begin{array}{l}\text { In my school, teachers' } \\
\text { responsibilities differ from } \\
\text { one teacher to another } \\
\text { based on their } \\
\text { qualifications and } \\
\text { experience. }\end{array}$ & 5 & 4 & 3 & 2 & 1 \\
\hline (15) & $\begin{array}{l}\text { The general rules as set by } \\
\text { your school regarding } \\
\text { teachers' responsibilities } \\
\text { are effective and clear. }\end{array}$ & 5 & 4 & 3 & 2 & 1 \\
\hline
\end{tabular}

QUESTIONS 16-19

RIGHTS OF PARENTS OF DISABLED STUDENTS

\begin{tabular}{|c|l|l|l|l|l|l|}
\hline S/N & Items & SA & A & N & D & SD \\
\hline (16) & $\begin{array}{l}\text { The school fully interacts } \\
\text { with the parents of disabled } \\
\text { students. }\end{array}$ & 5 & 4 & 3 & 2 & 1 \\
\hline (17) & $\begin{array}{l}\text { Parents of disabled } \\
\text { students are invited to } \\
\text { make special educational } \\
\text { plans. }\end{array}$ & 5 & 4 & 3 & 2 & 1 \\
\hline $\begin{array}{l}\text { The school provides a } \\
\text { mechanism for parents of } \\
\text { disabled students to } \\
\text { express their concerns. }\end{array}$ & 5 & 4 & 3 & 2 & 1 \\
\hline $\begin{array}{l}\text { Parents of disabled } \\
\text { students receive regular } \\
\text { notes, feedback and other } \\
\text { advices about their } \\
\text { children's social and } \\
\text { academic development. }\end{array}$ & 5 & 4 & 3 & 2 & 1 \\
\hline
\end{tabular}


QUESTIONS 20-23

ORGANIZATIONAL STRUCTURE OF SCHOOLS

\begin{tabular}{|c|c|c|c|c|c|c|}
\hline $\mathrm{S} / \mathrm{N}$ & Items & SA & $\mathrm{A}$ & $\mathrm{N}$ & $\mathrm{D}$ & SD \\
\hline$(20)$ & $\begin{array}{l}\text { Various disability } \\
\text { categories; special learning } \\
\text { disabilities, visual and } \\
\text { hearing impairment, autism } \\
\text { and other emotional and } \\
\text { behavioral disorders, are } \\
\text { accepted by your school. }\end{array}$ & 5 & 4 & 3 & 2 & 1 \\
\hline (21) & $\begin{array}{l}\text { The number of students } \\
\text { with disabilities who are } \\
\text { included in mainstream } \\
\text { classes is suitable to } \\
\text { enhance effective teaching } \\
\text { and learning. }\end{array}$ & 5 & 4 & 3 & 2 & 1 \\
\hline (22) & $\begin{array}{l}\text { The accommodations and } \\
\text { modifications made for } \\
\text { students with disabilities, } \\
\text { such as; providing sign } \\
\text { language interpreters for } \\
\text { deaf students, providing } \\
\text { large-print books for those } \\
\text { having visual impairment } \\
\text { and extending time for } \\
\text { those with learning } \\
\text { disabilities, are adequate } \\
\text { and sufficient to facilitate } \\
\text { teaching and learning. }\end{array}$ & 5 & 4 & 3 & 2 & 1 \\
\hline (23) & $\begin{array}{l}\text { Other special services and } \\
\text { facilities as provided by } \\
\text { your school in coordination } \\
\text { with the Ministry of } \\
\text { Education, such as; speech } \\
\text { and language services, } \\
\text { physical therapy, } \\
\text { occupational therapy.....etc } \\
\text { are enough to enhance } \\
\text { equal opportunities. }\end{array}$ & 5 & 4 & 3 & 2 & 1 \\
\hline
\end{tabular}

QUESTIONS 24-27

CURRICULAR AND ASSESSMENT SYSTEM

\begin{tabular}{|c|c|c|c|c|c|c|}
\hline S/N & Items & SA & $\mathrm{A}$ & $\mathrm{N}$ & $\mathrm{D}$ & SD \\
\hline (24) & $\begin{array}{l}\text { Curricular are designed in } \\
\text { away allowing for full } \\
\text { interaction of students in } \\
\text { inclusive classrooms } \\
\text { regardless of their abilities } \\
\text { or disabilities. }\end{array}$ & 5 & 4 & 3 & 2 & 1 \\
\hline (25) & $\begin{array}{l}\text { Curricular and assessments } \\
\text { are properly modified to } \\
\text { suit disabled students. }\end{array}$ & 5 & 4 & 3 & 2 & 1 \\
\hline (26) & $\begin{array}{l}\text { There are clear guidelines } \\
\text { governing the process of } \\
\text { designing, implementing } \\
\text { and evaluating curricular } \\
\text { and assessments. }\end{array}$ & 5 & 4 & 3 & 2 & 1 \\
\hline (27) & $\begin{array}{l}\text { Teachers are effectively } \\
\text { involved in making } \\
\text { flexible learning and } \\
\text { assessment plans for their } \\
\text { students as per their } \\
\text { capabilities. }\end{array}$ & 5 & 4 & 3 & 2 & 1 \\
\hline
\end{tabular}

THIRD PART

Please use your own views to provide rich answers to the following questions. You can use the back side of the paper to provide further details on each question below.

28. Do you think that inclusion of students with disabilities into regular education classrooms in the UAE is successful? Why?

29. What are the constraints you encounter when teaching in inclusive classes?

30. How can inclusive education best be applied to achieve successful and effective teaching and learning for both disabled and non-disabled students? 
31. Any further suggestions or recommendations regarding inclusive education in the UAE?

\section{REFERENCES}

[1] Ajzen, I. (2011). Attitudes, personality and behavior (2nd edn). Maidenhead, Berkshire: Open University Press.

[2] Ajzen, I. \& M. Fishbein. (2002). Understanding attitudes and predicting social behavior. Englewood Cliffs, N.J.: Prentice-Hall.

[3] Alahbabi, A. (2009). K-12 special and general education teachers' attitudes toward the inclusion of students with special needs in general education classes in the United Arab Emirates (UAE). International Journal of Special Education, 24.2, 42-54.

[4] Albarracin, D., M. Zanna, B. Johnson \& G. Kumkale. (2005). Attitudes: Introduction and scope. In D. Albarracin, B. Johnson \& M. Zanna (eds.), The handbook of attitudes. Mahwah, NJ: Lawrence Erlbaum, 3-20.

[5] Albert, B. (2006). Briefing notes: The social model of disability, human rights and development: Disability KaR research project: Enabling disabled people to reduce poverty [online]. [Accessed 17 February 2018]. Available at: https://pdfs.semanticscholar.org/3ada/f481faab930f323658fd447e9a0ef71d0b68.pdf?_ga=2.82623766.1212957215.152078995 8-1575619947.1520789958.

[6] Anati, N. M. (2012). Including students with disabilities in UAE schools: A descriptive study. International Journal of Special Education, 27.2, 75-85.

[7] Arif, M. \& E. Gaad. (2008). Special needs education in the United Arab Emirates (UAE): A system perspective. Journal of Research in Special Educational Needs, 8.2, 111-117.

[8] Bladd, J. (2010). Prejudice hampers effort to get UAE's disabled into work. Arabian Business [online]. 20 July, 11:49 AM. [Accessed 19 February 2018]. Available at: http://www.arabianbusiness.com/593080-prejudice-hampers-effort-to-get-uaedisabled-into-work.

[9] Carsrud, A., M. Brannback, J. Elfving \& K. Brandt. (2009). Motivations: The entrepreneurial mind and behavior. In A. Carsrud \& M. Brannback (eds.), Understanding the entrepreneurial mind: Opening the black box. London: Springer, 141-166.

[10] Cooper, J., W. D. Crano \& J. P. Forgas. (2010). The psychology of attitudes and attitude change. Hoboken: Taylor \& Francis.

[11] Creswell, J. W. (2014). Research design: Qualitative, quantitative, and mixed methods approaches (4th edn). Thousand Oaks, California: SAGE Publications.

[12] Daniel, L. G. \& D. A. King. (1997). Impact of inclusion education on academic achievement, student behavior and self-esteem, and parental attitudes. Journal of Educational Research, 91.2, 67-80.

[13] Engelbrecht, P., M. Oswald \& C. Forlin. (2006). Promoting the implementation of inclusive education in primary schools in South Africa. British Journal of Special Education, 33.3, 121-129.

[14] Fetterman, D. M. (2010). Ethnography: Step by step (3rd edn). Thousand Oaks, CA: Sage.

[15] Finkelstein, V. (2004). Representing disability. In J. Swain, S. French, C. Barnes \& C. Thomas (eds.), Disabling barriers enabling environments (2nd edn). London: Sage, Ch. 2.

[16] Forlin, C. \& D. Chambers. (2011). Teacher preparation for inclusive education: Increasing knowledge but raising concerns. Asia-Pacific Journal of Teacher Education, 39.1, 17-32.

[17] French, S. \& J. Swain. (2004). Whose tragedy: Towards a personal non-tragedy view of disability. In J. Swain, S. French, C. Barnes \& C. Thomas (eds.), Disabling barriers - enabling environments (2nd edn). London: Sage, Ch. 5.

[18] Gaad, E. (2004). Pre-service teachers' attitudes towards a career in special education in the United Arab Emirates. College Student Journal, 38.4, 619-632.

[19] Gaad, E. (2011). Inclusive education in the Middle East. New York: Routledge.

[20] Gaad, E. \& M. Almotairi. (2013). Inclusion of student with special needs within higher education in UAE: Issues and challenges. Journal of International Education Research, 9.4, 287-292.

[21] Gaad, E. \& L. Khan. (2007). Primary mainstream teachers' attitudes towards inclusion of students with special educational needs in the private sector: A perspective from Dubai. International Journal of Special Education, 22.2, 95-108.

[22] Gall, M. D., J. P. Gall \& W. R. Borg. (2007). Educational research: An introduction (8th edn). Boston: Pearson/Allyn \& Bacon.

[23] Kauffman, J. M., T. J. Landrum, D. R. Mock, B. Sayeski \& K. L. Sayesk (2005). Diverse knowledge and skills require a diversity of instructional groups. Remedial and Special Education, 26.1, 2-6.

[24] Meijer, C. (2003). Inclusive education and effective classroom practices [online]. European Agency for Development in Special Needs Education. [Accessed 12 February 2018]. Available at: https://www.europeanagency.org/sites/default/files/inclusive-education-and-classroom-practices_iecp-en.pdf.

[25] Ministry of Education (MOE) (2010). School for all: General rules for the provision of special education programs and services (public \& private schools) [online]. UAE: Dubai. [Accessed 02 February 2018]. Available at: https://www.moe.gov.ae/English/SiteDocuments/Rules/SNrulesEn.pdf.

[26] Oliver, M. (2004). If I had a hammer: The social model in action. In J. Swain, S. French, C. Barnes \& C. Thomas (eds.), Disabling barriers - enabling environments (2nd edn). London: Sage, Ch. 1.

[27] Pavri, S. \& L. Monda-Amaya. (2001). Social support in inclusive schools: Students' and teachers' perspectives. Exceptional Children, 67.3, 391-411.

[28] Shakespeare, T. \& N. Watson (eds.) (2009). The social model of disability: An outdated ideology? Research in Social Science and Disability (vol. 2). Bingley: Emerald Group Publishing Limited, 9-28.

[29] Sutton, S. (1998). Predicting and explaining intentions and behavior: How well are we doing? Journal of Applied Social Psychology, 28.15, 1317-1338.

[30] Thomas, C. (2004). How is disability understood? An examination of sociological approaches. Disability \& Society, 19.6, 569583.

[31] Thorpe, A, \& A. Q. M. S. Azam. (2010). Teachers' perceptions of inclusive education in mainstream primary schools in the United Kingdom. The International Journal of Interdisciplinary Social Sciences: Annual Review, 5.3, 163-172. 
[32] United Nations (UN). (2006). Convention on the rights of persons with disabilities [online]. [Accessed 09 February 2018 ]. Available at: http://www.un.org/disabilities/documents/convention/convoptprot-e.pdf.

[33] Wolcott, H. F. (2008). Ethnography: A way of seeing (2nd edn). Lanham, MD: Altamira Press.

[34] Zint, M. (2002). Comparing three attitude-behavior theories for predicting science teachers' intentions. Journal of Research in Science Teaching, 39.9, 819-844.

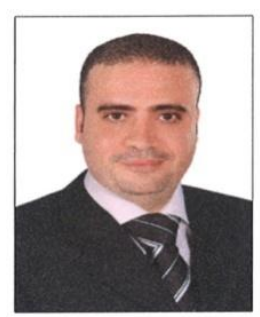

Haytham M. Badr was born in Mansoura, Egypt in 1983. Badr is currently studying as a Ph.D student in Education, TESOL at the British University in Dubai, United Arab Emirates. He achieved his master degree in Education, TESOL from the British University in Dubai in 2017, his two post-graduate diplomas in Education, curriculum and teaching methods/ English department from Tanta University, Egypt in 2007-2008 and his bachelor degree in simultaneous interpretation/ English department from Al-Azhar University, Cairo, Egypt in 2006.

He currently works both as an English language instructor and as an English-Arabic interpreter in AbuDhabi government, UAE. He also worked as an English instructor, translator, interpreter and English teacher in Mansoura University, Egypt. His research interests include L2 teaching and learning, discourse analysis, curriculum and innovation, educational policy, inclusive education and translation.

Mr. Badr is a member of a non-profit association based in Egypt to provide recommendations for the development of English instructional materials as well as providing free of charge English teaching services for indigents and a member of translators' association to improve different types of written translation through free online courses and discussions. 